\title{
Adiposity factors are not related to the presence of colorectal adenomas
}

This article was published in the following Dove Press journal:

Clinical and Experimental Gastroenterology

I4 November 201।

Number of times this article has been viewed

\section{Aris Chronis \\ Konstantinos Thomopoulos \\ Apostolos Sapountzis \\ Christos Triantos \\ Maria Kalafateli \\ Charalampos Kalofonos \\ Vassiliki Nikolopoulou}

Department of Internal Medicine, Division of Gastroenterology,

University Hospital, Patras, Greece

Correspondence: Konstantinos

Thomopoulos

University of Patras Medical School,

Parodos Kimothois 6, 26443 Patras,

Greece

Tel +306977563564

Fax +32 26I0993982

Email kxthomo@hotmail.com
Purpose: Adiposity has been thought to be related to colorectal carcinogenesis. The aim of this study was to explore any association between obesity factors and the presence of colorectal adenoma, a potential precancerous lesion.

Patients and methods: Two hundred and six consecutive patients undergoing colonoscopy without colorectal cancer were enrolled in the study. Anthropometric measures and other adiposity-related laboratory variables including insulin resistance and serum adiponectin levels were recorded and correlated with the presence of adenoma.

Results: Colorectal adenoma was detected in 68/206 patients (33\%), tubular adenoma(s) in 38 patients, and tubulovillous or villous in 30 patients. Twenty-one patients $(10.2 \%)$ had at least one proximal polyp. The size of the largest adenoma was $\leq 10 \mathrm{~mm}$ in 40 patients and $>10 \mathrm{~mm}$ in 28 patients. No statistically significant difference was observed in body mass index, waist circumference, fasting plasma glucose concentration, insulin, homeostatic metabolic assessment, cholesterol, low-density lipoproteins, high-density lipoprotein, or triglycerides between patients with and without adenoma. In addition, there was no difference in plasma adiponectin between patients with adenoma $(11.1 \pm 6 \mu \mathrm{g} / \mathrm{mL})$ and controls $(10.2 \pm 7.8 \mu \mathrm{g} / \mathrm{mL})$. Furthermore, no significant difference in any parameter was found between patients with advanced adenoma and no advanced adenoma, nor between patients with proximal or distal tumors.

Conclusion: This study found that the presence of colorectal adenoma is not correlated with any adiposity factor. Moreover, obesity does not appear to be associated with the site or the presence of more advanced lesions.

Keywords: adiposity, colorectal adenoma, polyp, adiponectin

\section{Introduction}

Obesity has been associated with increased risk not only for cardiovascular disease, diabetes, and hypertension, but also for malignant disease in various organs. ${ }^{1}$ A positive association has been reported between adiposity, particularly central adiposity, and colon cancer. ${ }^{1-3}$ As obesity influences insulin status, it is hypothesized that colon neoplasia is through insulin resistance and insulin-like growth factors. ${ }^{4}$

Considering that colorectal adenomatous polyps are recognized as precancerous lesions, a possible association with obesity has been explored in previous studies with controversial results. Adiposity and/or central adiposity parameters have been associated with increased risk of adenoma in some studies ${ }^{5-8}$ but not in others. ${ }^{9-11}$ Given that adenomatous polyps are common, but only a minority progress to high dysplasia and cancer, the role of adiposity in this process is also unknown. 
In recent years adipose tissue has been increasingly viewed not only as a storage organ but also as an active organ that produces a variety of proteins with various actions. Adipocytokines - adipose tissue-derived proteins - including leptin, tumor necrosis factor alpha, resistin, and adiponectin, have an active role in energy homeostasis and have been linked to many aspects of the metabolic syndrome in many recent human and animal studies. ${ }^{12-16}$ Increasing evidence suggests that adiponectin plays an important role in the pathophysiology of the metabolic syndrome and that its levels correlate inversely with body mass index (BMI), plasma triglyceride levels and fasting insulin concentration. ${ }^{12-15}$ Recent data have also revealed that adiponectin probably interferes with immunity and carcinogenesis. ${ }^{16-19}$

The aim of this study was to explore any association between obesity factors, including serum adiponectin levels and the presence of colorectal adenoma, as well as the site and presence of advanced lesion in a large number of patients undergoing colonoscopy.

\section{Patients and methods}

All patients included in this study underwent colonoscopy in the authors' department between May 2010 and December 2010. Colonoscopy was performed by two experienced gastroenterologists during a voluntary health check-up or for other indications - mainly because of occult or overt fecal blood loss or a change in bowel movement habits. Bowel preparations were carried out using $4 \mathrm{~L}$ of polyethylene glycol solution (Klean-Prep, Kite Hellas, Athens, Greece). Patients with polyps underwent polypectomy and a histological examination for each polyp was obtained. Among multiple polyps the highest dysplasia was considered. A polyp was categorized as proximal when localized in cecum, ascending and transverse colon, and distal in descending, sigmoid colon and rectum. Advanced adenoma was defined as an adenoma more than $10 \mathrm{~mm}$ in diameter and/or with high-grade dysplasia and/or containing villous component (at least 25\% villous).

Patients with invasive colorectal cancer detected during colonoscopy and patients with previous colectomy or polypectomy were excluded from the analysis. Patients with other malignancies or active systematic disease, as well as those under dietary or drug treatment for diabetes mellitus, were also excluded.

Anthropometric data, including body weight, height, body mass index (BMI) and waist circumference, were recorded.

Venous blood samples were collected after an overnight fast to determine the serum levels of glucose, insulin,
C-peptide, cholesterol, triglyceride, high-density lipoprotein (HDL), and low-density lipoprotein (LDL). Insulin resistance was calculated by the homeostatic metabolic assessment - insulin resistance (HOMA-IR) method as follows: HOMA-IR = fasting plasma insulin $\times$ fasting plasma glucose/405, whereas insulin is expressed in microunits $/ \mathrm{mL}$ and glucose in $\mathrm{mg} / \mathrm{d}$.

Venous blood for the assessment of plasma concentration of adiponectin was drawn from all subjects after overnight fasting. Serum adiponectin levels were measured with radioimmunoassay (Human Adiponectin RIA Kit; Linco ${ }^{\circledR}$ Research, Inc, St Charles, MO).

This study protocol was approved by the University Faculty of Medicine Ethical Committee. Written, informed consent was obtained in advance from all subjects.

Differences of age, gender, fasting glucose, insulin concentration, HOMA-IR, BMI, waist circumference, and plasma adiponectin levels between patients with adenoma and controls were assessed. Continuous variables were expressed as mean \pm standard deviation and were compared using Student's $t$-test. Categorical variables were expressed as percentages and differences between groups were tested for significance by using the chi-square test. All analyses were conducted by using statistical software (SPSS v 16.0; IBM Corp, Armonk, NY).

\section{Results}

Two hundred and six consecutive patients, 119 males and 87 females, with a mean age of $64.7 \pm 10.5$ years, were enrolled in the study. Colorectal adenoma was detected in 68 patients $(33 \%)$. The histology was that of tubular adenoma in 38 patients and tubulovillous or villous in 30 patients.

Twenty-one patients $(10.2 \%)$ had at least one proximal polyp, 41 patients had one polyp, while in 27 , two or more adenomas were detected. The size of the largest adenoma was $\leq 10 \mathrm{~mm}$ in 40 patients and $>10 \mathrm{~mm}$ in 28 patients, as can be seen in Table 1 .

The two groups were comparable. Age was not significantly different between the patients with and without colorectal adenoma ( $65.8 \pm 11$ years vs $64.5 \pm 10.1$ years $)$. Moreover, no difference was observed in gender between the patients and the controls (38/68 vs 81/138 males).

No statistically significant difference was observed in BMI, waist circumference, fasting plasma glucose concentration, insulin, HOMA, cholesterol, LDL, HDL, and triglycerides between the two groups. In addition, plasma adiponectin was not different: $11.1 \pm 6 \mu \mathrm{g} / \mathrm{mL}$ in patients with adenoma, $10.2 \pm 7.8 \mu \mathrm{g} / \mathrm{mL}$ in controls $(P=0.41)$. 
Table I Characteristics of participants without adenoma versus those with no advanced and advanced adenoma

\begin{tabular}{llll}
\hline & $\begin{array}{l}\text { Patients without adenoma } \\
(\mathbf{N}=\mathbf{~ I 3 8 )}\end{array}$ & $\begin{array}{l}\text { No advanced adenoma } \\
(\mathbf{N}=\mathbf{2 2})\end{array}$ & $\begin{array}{l}\text { Patients with advanced adenoma } \\
\mathbf{( N = 4 6 )}\end{array}$ \\
\hline Age (years) & $63.5 \pm 10.1$ & $65.1 \pm 12.0$ & $66.2 \pm 10.7$ \\
Male/female & $81 / 57$ & $12 / 10$ & $26 / 20$ \\
Smoker $(\%)$ & $42(30.4)$ & $7(31.8)$ & $12(26.1)$ \\
Drinker* $(\%)$ & $54(24.6)$ & $73.2 \pm 9.1$ & $13(28.3)$ \\
Body weight $(\mathrm{kg})$ & $76.7 \pm 13.7$ & $99.3 \pm 8.4$ & $75.6 \pm 14.1$ \\
Waist circumference $(\mathrm{cm})$ & $99.9 \pm 10.9$ & $26.4 \pm 3.1$ & $99.2 \pm 12.2$ \\
BMI $\left(\mathrm{kg} / \mathrm{m}^{2}\right)$ & $27.4 \pm 4.7$ & $96.2 \pm 12.3$ & $27.1 \pm 4.2$ \\
Glucose $(\mathrm{mg} / \mathrm{dL})$ & $100.4 \pm 26.7$ & $204.2 \pm 46.8$ & $102.6 \pm 20.5$ \\
Cholesterol $(\mathrm{mg} / \mathrm{dL})$ & $197.8 \pm 41$ & $120.5 \pm 38.9$ & $201.5 \pm 46$ \\
LDL $(\mathrm{mg} / \mathrm{dL})$ & $116.3 \pm 32.9$ & $52.7 \pm 11.9$ & $112.7 \pm 39.5$ \\
HDL $(\mathrm{mg} / \mathrm{dL})$ & $52.2 \pm 14.3$ & $146.4 \pm 54.2$ & $53.2 \pm 16.5$ \\
Triglycerides $(\mathrm{mg} / \mathrm{dL})$ & $138.8 \pm 52.1$ & $5.8 \pm 4.6$ & $122.9 \pm 54.1$ \\
Insulin $(\mu \mathrm{U} / \mathrm{dL})$ & $5.9 \pm 3.6$ & $2.5 \pm 1.7$ & $7.1 \pm 5.4$ \\
C-peptide $(\mathrm{ng} / \mathrm{mL})$ & $2.4 \pm 1.1$ & $1.0 \pm 0.6$ & $2.8 \pm 1.3$ \\
HOMA & $1.1 \pm 0.7$ & $10.9 \pm 5.6$ & $1.3 \pm 1.3$ \\
Adiponectin $(\mu \mathrm{g} / \mathrm{mL})$ & $10.2 \pm 7.8$ & & $11.2 \pm 6.3$ \\
\hline
\end{tabular}

Note: *Drinker was defined as drinking more than one drink per day.

Abbreviations: BMI, body mass index; HDL, high-density lipoprotein; HOMA, homeostatic metabolic assessment; LDL, low-density lipoprotein.

In addition, no significant difference in any parameter was found between patients with advanced adenoma and no advanced adenoma (Table 1). Furthermore, no statistically significant difference was observed in any parameter between patients with proximal or distal adenomas (Table 2).

\section{Discussion}

Adiposity has been correlated with colon cancer in previous studies. The association was strong for men but only weak for women. ${ }^{3}$ In another study, only central adiposity and no other

Table 2 Characteristics of participants with proximal versus distal adenoma

\begin{tabular}{lll}
\hline & $\begin{array}{l}\text { With proximal } \\
\text { adenoma }(\mathbf{N}=\mathbf{2 I})\end{array}$ & $\begin{array}{l}\text { With distal } \\
\text { adenoma }(\mathbf{N}=\mathbf{4 7})\end{array}$ \\
\hline Age (years) & $65.1 \pm 11.4$ & $66.6 \pm 10.8$ \\
Male/Female & $9 / 13$ & $22 / 24$ \\
Body weight $(\mathrm{kg})$ & $74.1 \pm 10.1$ & $74.4 \pm 13.8$ \\
Waist & $98.7 \pm 11.5$ & $99.1 \pm \mathrm{II} .6$ \\
circumference $(\mathrm{cm})$ & & \\
BMI $\left(\mathrm{kg} / \mathrm{m}^{2}\right)$ & $26.4 \pm 3.3$ & $27.1 \pm 4.1$ \\
Glucose $(\mathrm{mg} / \mathrm{dL})$ & $98.6 \pm 18.6$ & $102.1 \pm 18.2$ \\
Cholesterol $(\mathrm{mg} / \mathrm{dL})$ & $207.4 \pm 62.6$ & $204.4 \pm 45.1$ \\
LDL $(\mathrm{mg} / \mathrm{dL})$ & $128.4 \pm 46.2$ & $111.3 \pm 40.6$ \\
HDL $(\mathrm{mg} / \mathrm{dL})$ & $50.2 \pm 17.2$ & $53.3 \pm 14.5$ \\
Triglycerides $(\mathrm{mg} / \mathrm{dL})$ & $148.2 \pm 65$ & $124.7 \pm 54.7$ \\
Insulin $(\mu \mathrm{U} / \mathrm{mL})$ & $6.3 \pm 3.6$ & $6.9 \pm 6.3$ \\
C-peptide $(\mathrm{ng} / \mathrm{mL})$ & $2.9 \pm 1.7$ & $2.7 \pm 1.3$ \\
HOMA & $0.9 \pm 0.5$ & $1.3 \pm 1.2$ \\
Adiponectin $(\mu g / \mathrm{mL})$ & $11.7 \pm 8.3$ & $10.8 \pm 5.0$ \\
\hline
\end{tabular}

Abbreviations: BMI, body mass index; HDL, high-density lipoprotein; HOMA, homeostatic metabolic assessment; LDL, low-density lipoprotein. body size measures were associated with colorectal cancer risk. $^{2}$ In recent years an inverse correlation has been shown to exist between serum adiponectin levels and presence of colorectal carcinoma. ${ }^{20-22}$ It is not known whether the lower adiponectin levels result from weight changes and deranged metabolism or if adiponectin has a causative role per se. The mechanisms of possible adiponectin action have not yet been elucidated, but a variety of mechanisms has been postulated. Adiponectin might prevent carcinogenesis by inhibition of neovascularisation through antiangiogenetic mechanisms, suppression of tumor growth, and induction of apoptosis in various types of cancers. ${ }^{23,24}$

As the majority of colorectal cancers derive from adenomas, a possible association might be due either to increased risk of adenoma formation in obese patients or to increased probability of progression of adenomas in these patients.

In this study, no association was found between adiposity factors and the presence of colorectal adenomas in patients. Moreover, serum adiponectin levels were not different between patients with adenoma and controls. No correlation was found between any adiposity factor and the site of adenoma (proximal vs distal). In previous studies, adiposity as well as serum adiponectin levels have been correlated with the presence of adenoma. Fukumoto et al observed in patients with adenomatous polyps slightly lower serum adiponectin than in controls. ${ }^{25} \mathrm{~A}$ positive association between a variety of adiposity factors and adenomas has also been observed by other researchers. ${ }^{26-29}$ However, no association was found in other studies. ${ }^{21,30}$ The former studies were 
mainly from Japan and Korea whereas the latter were from Western countries. Patients from the Far East were younger (mean age 48-58 vs 56-63 years) and with lower BMI (mean BMI 22.8-23.7 vs 25.8-27) compared with patients from the West. Probably other factors, for example, diet, play a role in colorectal cancer carcinogenesis and not adiposity per se. In an experimental study, Fujisawa et al observed a significant increase in cell proliferative activity in the colonic epithelium of adiponectin-deficient mice when compared with wildtype mice fed a high-fat diet; however, no difference was observed between wild-type and adiponectin-deficient mice fed a basal diet. ${ }^{31}$ Also, genetic factors may contribute to the development and/or progression of a colorectal adenoma and the prevalence of these factors varies among different populations.

In a previous study, Sedjo et al found that weight gain was more strongly associated with the risk of colorectal adenoma than adiposity parameters at times more distant from the time of colonoscopy. ${ }^{32}$ Moreover, no association was found between serum adiponectin and adenoma recurrence in a prospective study where a large number of patients were followed up over a 4 -year period. ${ }^{33}$ In contrast, recurrence was correlated with serum homocysteine concentrations and a diet high in fat and low in fiber. ${ }^{33}$ These studies point out the role of current diet and body weight changes in the development and progression of colorectal tumors.

It is known that only a percentage of colorectal adenomas progress to advanced lesions and a very small percentage to cancer and this process takes several years, usually one to two decades. This study divided patients with adenomatous polyps into two groups: (1) those with severe dysplasia and/ or villous component and (2) those without. No difference was found between patients with advanced adenoma and those with nonadvanced adenoma.

Similar results were found in a study by Kumor et al, where no difference in the level of adipokines in serum was observed between patients with high-grade and low-grade dysplastic polyps. ${ }^{30}$ Also, Nakajima et al did not find any correlation between adiponectin and size of adenoma. ${ }^{26}$ However, positive association has been found between adiposity and presence of advanced tumors in other studies, where patients with advanced lesions presented even lower serum levels of adiponectin. ${ }^{26,28}$ In some studies, adiponectin levels were even lower in patients with colorectal cancer than patients with adenoma..$^{21,29,30}$ Decreased serum adiponectin is probably not involved in the development of colorectal cancer but results secondary to the derangements that occur during the development and progression of colon cancer.
This has not been studied in patients with colorectal cancer, but Ishikawa et al observed that serum adiponectin concentration was inversely correlated with tumor size and Tumor-Nodes-Metastasis Classification of Malignant Tumours stage in patients with gastric cancer. ${ }^{34}$

In conclusion, this study found that presence of colorectal adenoma is not correlated with any adiposity factor. However, further prospective studies on large patient populations from various countries with different diets and habits are needed to detect possible minor differences in any parameter and their association with colorectal adenoma.

\section{Disclosure}

The authors declare no conflicts of interest in this work.

\section{References}

1. Schoen RE, Tangen CM, Kuller LH, et al. Increased blood glucose and insulin, body size, and indent colorectal cancer. $J$ Natl Cancer Inst. 1999;91(13):1147-1154.

2. MacInnis RJ, English DR, Haydon AM, Hopper JL, Gertig DM, Giles GG. Body size and composition and risk of rectal cancer (Australia). Cancer Causes Control. 2006;17(10):1291-1297.

3. Pischon T, Lahmann PH, Boeing H, et al. Body size and risk of colon and rectal cancer in the European Prospective Investigation Into Cancer and Nutrition (EPIC). J Natl Cancer Inst. 2006;98(13):920-931.

4. Tsugane $\mathrm{S}$, Inoue $\mathrm{M}$. Insulin resistance and cancer: epidemiological evidence. Cancer Sci. 2010;101(5):1073-1079.

5. Johnson KT, Harmsen WS, Limburg PJ, Carston MJ, Johnson CD. Visceral fat analysis at CT colonography. Acad Radiol. 2006;13(8):963-938.

6. Kang HW, Kim D, Kim HJ, et al. Visceral obesity and insulin resistance as risk factors for colorectal adenoma: a cross-sectional, case-control study. Am J Gastroenterol. 2010;105(1):178-187.

7. Morimoto LM, Newcomb PA, Ulrich CM, Bostick RM, Lais CJ, Potter JD. Risk factors for hyperplastic and adenomatous polyps: evidence for malignant potential? Cancer Epidemiol Biomarkers Prev. 2002;11(10 Pt 1):1012-1018.

8. Terry MB, Neugut AI, Bostick RM, et al. Risk factors for advanced colorectal adenomas: a pooled analysis. Cancer Epidemiol Biomarkers Prev. 2002;11(7):622-629.

9. Lieberman DA, Prindiville S, Weiss DG, Willett W; VA Cooperative Study Group 380. Risk factors for advanced colonic neoplasia and hyperplastic polyps in asymptomatic individuals. JAMA. 2003;290(22): 2959-2967.

10. Bayerdörffer E, Mannes GA, Ochsenkühn T, Köpcke W, Wiebecke B, Paumgartner G. Increased risk of 'high-risk' colorectal adenomas in overweight men. Gastroenterology. 1993;104(1):137-144.

11. Stemmermann GN, Heilbrun LK, Nomura AM. Association of diet and other factors with adenomatous polyps of the large bowel: a prospective autopsy study. Am J Clin Nutr. 1988;47(2):312-317.

12. Hotta K, Funahashi T, Arita Y, et al. Plasma concentrations of a novel, adipose-specific protein, adiponectin, in type 2 diabetic patients. Arterioscler Thromb Vasc Biol. 2000;20(6):1595-1599.

13. Kumada M, Kihara S, Sumitsuji S, et al. Association of hypoadiponectinemia with coronary artery disease in men. Arterioscler Thromb Vasc Biol. 2003;23(1):85-89.

14. Kondo H, Shimomura I, Matsukawa Y, et al. Association of adiponectin mutation with type 2 diabetes: a candidate gene for the insulin resistance syndrome. Diabetes. 2002;51(7):2325-2328.

15. Ouchi N, Kihara S, Arita Y, et al. Adiponectin, an adipocyte-derived plasma protein, inhibits endothelial NF- $\mathrm{KB}$ signalling through a cAMPdependent pathway. Circulation. 2000;102(11):1296-1301. 
16. Ouchi N, Kihara S, Funahashi T, et al. Reciprocal association of $\mathrm{C}$-reactive protein with adiponectin in blood stream and adipose tissue. Circulation. 2003;107(5):671-674.

17. Engeli S, Feldpausch M, Gorzelniak K, et al. Association between adiponectin and mediators of inflammation in obese women. Diabetes. 2003;52(4):942-947.

18. Petridou E, Mantzoros C, Dessypris N, et al. Plasma adiponectin concentrations in relation to endometrial cancer: a case-control study in Greece. J Clin Endocrinol Metab. 2003;88(3):993-997.

19. Miyoshi Y, Funahashi T, Kihara S, et al. Association of serum adiponectin levels with breast cancer risk. Clin Cancer Res. 2003;9(15): 5699-5704.

20. Wei EK, Giovannucci E, Fuchs CS, Willett WC, Mantzoros CS. Low plasma adiponectin levels and risk of colorectal cancer in men: a prospective study. J Natl Cancer Inst. 2005;97(22):1688-1694.

21. Erarslan E, Turkay C, Koktener A, Koca C, Uz B, Bavbek N. Association of visceral fat accumulation and adiponectin levels with colorectal neoplasia. Dig Dis Sci. 2009;54(4):862-868.

22. Gonullu G, Kahraman H, Bedir A, Bektas A, Yücel I. Association between adiponectin, resistin, insulin resistance, and colorectal tumors. Int J Colorectal Dis. 2010;25(2):205-212.

23. Bråkenhielm E, Veitonmäki N, Cao R, et al. Adiponectin-induced antiangiogenesis and antitumor activity involve caspase-mediated endothelial cell apoptosis. Proc Natl Acad Sci U S A. 2004;101(8):2476-2481.

24. Michalakis K, Williams CJ, Mitsiades N, et al. Serum adiponectin concentrations and tissue expression of adiponectin receptors are reduced in patients with prostate cancer: a case control study. Cancer Epidemiol Biomarkers Prev. 2007;16(2):308-313.

25. Fukumoto J, Otake T, Tajima O, et al. Adiponectin and colorectal adenomas: Self Defense Forces Health Study. Cancer Sci. 2008;99(4): 781-786.
26. Nakajima TE, Yamada Y, Hamano T, et al. Adipocytokines as new promising markers of colorectal tumors: adiponectin for colorectal adenoma, and resistin and visfatin for colorectal cancer. Cancer Sci. 2010;101(5):1286-1291.

27. Yamaji T, Iwasaki M, Sasazuki S, Tsugane S. Interaction between adiponectin and leptin influences the risk of colorectal adenoma. Cancer Res. 2010;70(13):5430-5437.

28. Otake S, Takeda H, Suzuki Y, et al. Association of visceral fat accumulation and plasma adiponectin with colorectal adenoma: evidence for participation of insulin resistance. Clin Cancer Res. 2005;11(10):3642-3646.

29. Otake S, Takeda H, Fujishima S, et al. Decreased levels of plasma adiponectin associated with increased risk of colorectal cancer. World J Gastroenterol. 2010;16(10):1252-1257.

30. Kumor A, Daniel P, Pietruczuk M, Małecka-Panas E. Serum leptin, adiponectin, and resistin concentration in colorectal adenoma and carcinoma (CC) patients. Int J Colorectal Dis. 2009;24(3): 275-281.

31. Fujisawa T, Endo H, Tomimoto A, et al. Adiponectin suppresses colorectal carcinogenesis under the high-fat diet condition. Gut. 2008 ; 57(11):1531-1538.

32. Sedjo RL, Byers T, Levin TR, et al. Change in body size and the risk of colorectal adenomas. Cancer Epidemiol Biomarkers Prev. 2007; 16(3):526-531.

33. Bobe G, Murphy G, Rogers CJ, et al. Serum adiponectin, leptin, C-peptide, homocysteine, and colorectal adenoma recurrence in the Polyp Prevention Trial. Cancer Epidemiol Biomarkers Prev. 2010; 19(6):1441-1452.

34. Ishikawa M, Kitayama J, Kazama S, Hiramatsu T, Hatano K, Nagawa H. Plasma adiponectin and gastric cancer. Clin Cancer Res. 2005;11(2 Pt 1):466-472.
Clinical and Experimental Gastroenterology

\section{Publish your work in this journal}

Clinical and Experimental Gastroenterology is an international, peerreviewed, open access journal, publishing all aspects of gastroenterology in the clinic and laboratory, including: Pathology, pathophysiology of gastrointestinal disease; Investigation and treatment of gastointestinal disease; Pharmacology of drugs used in the alimentary tract;

\section{Dovepress}

Immunology/genetics/genomics related to gastrointestinal disease. This journal is indexed on CAS. The manuscript management system is completely online and includes a very quick and fair peer-review system. Visit http://www.dovepress.com/testimonials.php to read real quotes from published authors. 